\title{
Magnetite coupling in a PS/PMMA block copolymer using suspension polymerization
}

\section{Acoplamiento de magnetita en un copolímero PS/PMMA usando polimerización por suspensión}

CARMONA-TORRES Marco ${ }^{\prime}$, FUENTES-RAMÍREZ, Rosalba', CONTRERAS-LOPEZ, David' and GALINDO-GONZÁLEZ, Rosario"**

'Dept. of Chemical Engineering, Division of Natural and Exact Sciences, Universidad de Guanajuato, Noria Alta S/N, Guanajuato, Gto. México 36050

"CONACYT Chair Universidad de Guanajuato, Division of Natural and Exact Sciences.

ID $1^{\text {st }}$ Author: Marco, Carmona-Torres

ID $1^{\text {st }}$ Coauthor: Rosalba, Fuentes-Ramírez / ORC ID: 0000-0003-0520-3387, CVU CONACYT ID: 202669

ID $2^{\text {nd }}$ Coauthor: David, Contreras-Lopez / ORC ID: 0000-0003-1384-4766, CVU CONACYT ID: 38297

ID $3^{\text {rd }}$ Coauthor: Rosario, Galindo-González / ORC ID: 0000-0002-3612-1555, CVU CONACYT ID: 223987

DOI: $10.35429 /$ EJB.2020.12.7.23.27

Received: January 10, 2020; Accepted: June 30, 2020

\begin{abstract}
The objective of the present article is to introduce nanoparticles of a ferromagnetic material (magnetite) to the polymer matrix. We will make some study to verify that the coupling of the nanoparticles in the material was carried out. The present work describes the self-assembly of nanocomposite in suspensión polymerization of PS/PMMA block copolymer, containing magnetite $\left(\mathrm{Fe}_{3} \mathrm{O}_{4}\right)$ which is sonicated with the monomer mixture, with percentages of $0.25 \%$ and $0.5 \%$ in proportion of the weight of mixture. Photographs were taken with the microscope to verify the coupling of the ferromagnetic material to the polymer matrix, and to verify that couplig, we made characterization by infrared spectroscopy. Also describes the process of nanocomposite synthesis using co-precipitation method, in which ferric chloride and ferrous chloride are combined in an excess basic medium, to subsequently induce the precipitation of the material with a magnet.
\end{abstract}

\begin{abstract}
Resumen
El objetivo del presente artículo es introducir nanoparticulas de un material ferromagnético (magnetita) a la matriz polimérica. Se efectuaron pruebas para comprobar que se llevó a cabo el acoplamiento de dichas nanopartículas en el material. En este trabajo se describe el auto ensamblaje de un nanocomposito, utilizando el método de polimerización por suspensión de una mezcla de polímeros (PS/PMMA) en combinación con magnetita $\left(\mathrm{Fe}_{3} \mathrm{O}_{4}\right)$, la cual fue sonicada con la mezcla de monómeros, conteniendo porcentajes de $0.25 \%$ y $0.5 \%$ en proporción del peso de la mezcla de monómeros. Se tomaron fotografías con el microscopio para comprobar el acoplamiento del material ferromagnético a la matriz polimérica, y se llevó a cabo la caracterización mediante espectrometría infrarroja para corroborar dicho acoplamiento. También se describe el proceso de síntesis del nanocomposito utilizando el método de coprecipitación, en el cual se combinan cloruro férrico y cloruro ferroso en un medio básico en exceso, para posteriormente inducir la precipitación del material con un imán.
\end{abstract}

\section{Magnetita, Copolímero, Nanocomposito}

\footnotetext{
* Correspondence to Author (Email: mr.galindo@ugto.mx)

$\dagger$ Researcher contributing as first author.
} 


\section{Introduction}

The objective of the present article is to introduce nanoparticles of a ferromagnetic material (magnetite) to the polymer matrix. We will make some study to verify that the coupling of the nanoparticles in the material was carried out.

Suspension polymerization is a process in which the polymerization of relatively waterinsoluble monomer droplets formed by vigorous stirring in the presence of a steric stabilizer leads to an aqueous dispersion of polymer particles [1]. The interfacial tension, the degree of agitation, and the design of the stirrer/reactor system govern the dispersion of monomer droplets. The presence of suspending agents (e.g., stabilizers) hinder the coalescence of monomer droplets and the adhesion of partially polymerized particles during the course of polymerization, so that the solid beads may be produced in the same spherical form in which the monomer was dispersed in the aqueous phase [2]. Under proper experimental conditions, block copolymers, which are composed of chemically different blocks, can self- assemble at the nanometer scale, into various well-defined morphologies corresponding to the molecular dimensions of each block. Recent studies have found that incorporation of nanoparticles (NPs) into self-assembled block copolymers can greatly improve the mechanical strength, electrical conductivity, and optical properties of this composite [3], and the magnetic properties will provide future opportunities in technologies such as solar cells, photonic bandgap materials, and high-density magnetic storage devices [4].

The present work describes the selfassembly of nanocomposite in suspension polymerization of PS/PMMA block copolymer (see Figure 1), containing magnetite $\left(\mathrm{Fe}_{3} \mathrm{O}_{4}\right)$ which is sonicated with the monomer mixture, with percentages of $0.25 \%$ and $0.5 \%$ in proportion of the weight of mixture. Photographs were taken with the microscope to verify the coupling of the ferromagnetic material to the polymer matrix, and to verify that coupling, we made characterization by infrared spectroscopy. Also describes the process of nanocomposite synthesis using co-precipitation method, in which ferric chloride and ferrous chloride are combined in an excess basic medium, to subsequently induce the precipitation of the material with a magnet.

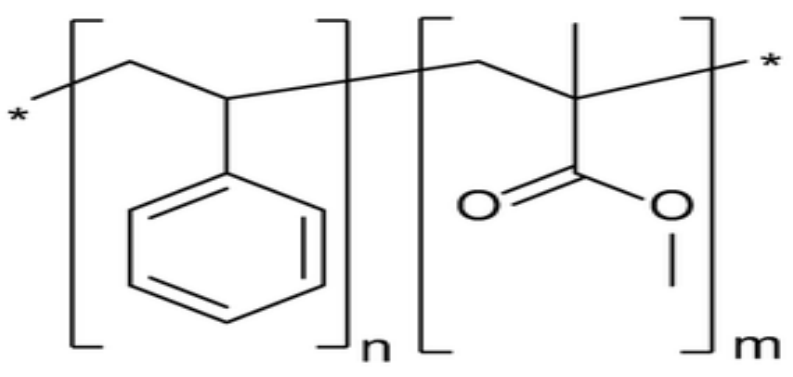

Figure 1 Structure of PS/PMMA block copolymer Source: (Bennett et al., 2014)

\section{Methodology}

Reagents

Monomer: Styrene and methyl methacrylate with a purity percentage > 99\% sigma Aldrich. We have to eliminate the inhibitors washing the monomer with sodium hydroxide $0.1 \mathrm{M}$ solution. (PVA).

Dispersing agent: polyvinyl alcohol

Initiator: Benzoyl peroxide (BPO) purity percentage $97 \%$

\section{Polymerization of block copolymer:}

We use the suspension polymerization method. The reactions were carried out in a $500 \mathrm{~mL}$ batch reactor, using as continuous phase $45 \mathrm{~mL}$ of PVA with a concentration of $5 \mathrm{~g} / \mathrm{L}$. We combined $10 \mathrm{~mL}$ of the monomer mixture (styrene 90\%/ Methyl methacrylate 10\%) with $025 \%$ and $0.5 \%$ of magnetite according with the weight of the mixture (approximately $9.09 \mathrm{~g}$ ). After that, we sonicate the mixture with the magnetite for $10 \mathrm{~min}$ to disperse the particles into monomers. We added the initiator after sonicating and proceed to added it to the reactor when the PVA reach the temperature of the reaction $\left(75^{\circ} \mathrm{C}\right)$, with constant agitation of 130 rpm with mechanical agitation.

Time of reaction: $3 \frac{1}{2} 2$ hours.

\section{Synthesis of magnetite:}

For the magnetite synthesis we aggregate 100 $\mathrm{mL}$ of potassium hydroxide $(\mathrm{KOH}) 2 \mathrm{M}$ to a beaker and heat to $60^{\circ} \mathrm{C}$. 
For the chlorides, we prepare $10 \mathrm{~mL}$ of ferrous chloride $\left(\mathrm{FeCl}_{2}\right) 0.1 \mathrm{M}$ and $10 \mathrm{~mL}$ of ferric chloride $\left(\mathrm{FeCl}_{3}\right) 0.05 \mathrm{M}$ and were added drop by drop with constant agitation.

After 30 minutes, we turn off the heating and precipitate the magnetite with a magnet, adding ethanol to wash the remanent water. After that, we put the magnetite on a stove to dry it.

\section{Results}

A TEM microscopy obtained at a resolution of $50 \mathrm{~nm}$ is shown in Figure 2, a magnetite with an average size of $30 \mathrm{~nm}$ being observed, spherical and denoting that the particles are structurally homogeneous.

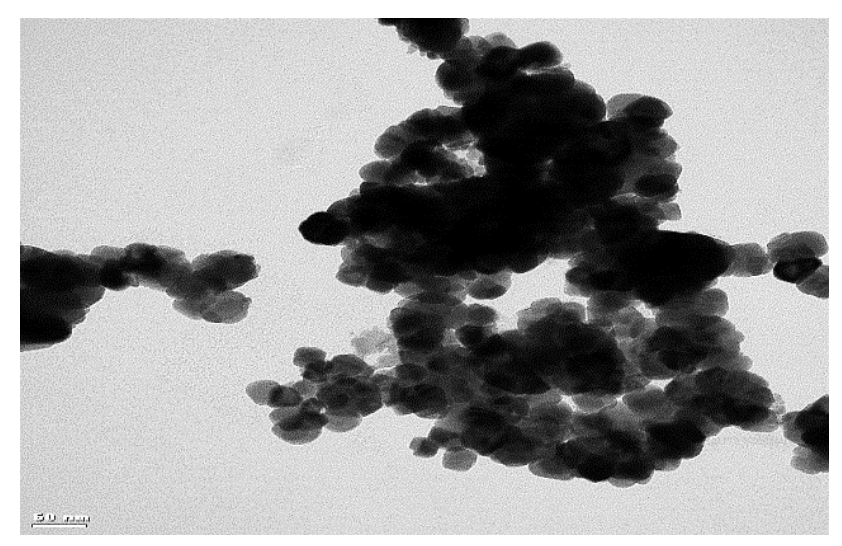

Figure 2 TEM Microscopy of magnetite

As can be seen in Graphic 1, a comparison made with the theoretical structure of magnetite (blue dots) and the experimentally elaborated (red curve), showing that the peaks coincide in $99 \%$, being at the peak that is a value of $2 \Theta$ of 36 where $\mathrm{Fe}$ is found.

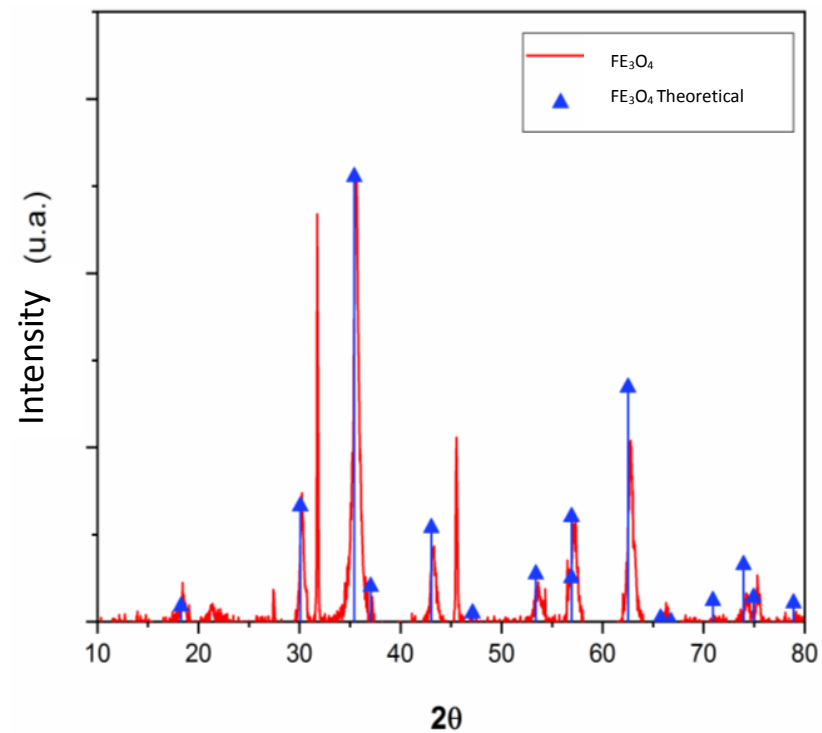

Graphic 1 X-ray diffractogram comparing Theoretical vs Experimental magnetite

The FT-IR spectra that verify the presence of $\mathrm{Fe}_{3} \mathrm{O}_{4}$ are observed in Graphic 2. It was carried out on $\mathrm{KBr}$ plates since they allow to visualize the part of the spectrum that goes from 4000 to $400 \mathrm{~cm}^{-1}$ and $\mathrm{ZnO}$ has between 650- $720 \mathrm{~cm}-1$ its characteristic peak of the Fe$\mathrm{O}$ bond using $\mathrm{MeOH}$ to disperse them.

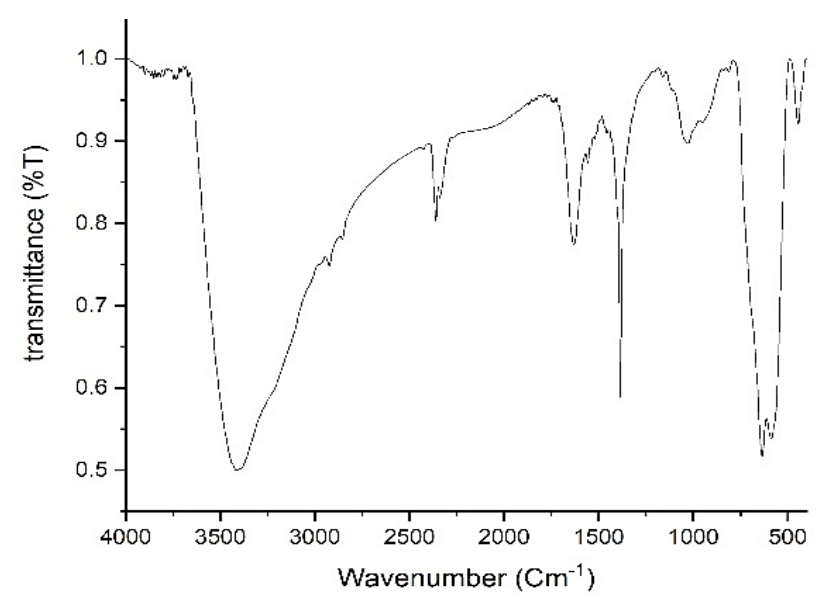

Graphic 2 Magnetite IR spectrum

Graphic 3 shows the infrared spectrum of copolymer polystyrene/methyl methacrylate. In this case, band of an aromatic monosubstituted is in region to $1940-1745 \mathrm{~cm}^{-1}$, bands of stretching C-H bonds between $3080-3090 \mathrm{~cm}^{-1}$, bands of stretching $\mathrm{CH}_{2}$ bonds between 2920$2850 \mathrm{~cm}^{-1}$ and band between 750 to $690 \mathrm{~cm}^{-1}$ corresponds to the mono-substitution of the ring. Perhaps, $1600 \mathrm{~cm}^{-1}$ correspond the bond $\mathrm{C}=\mathrm{C}$ and between $1490-1450 \mathrm{~cm}^{-1}$ the bond C-C. The bands of the $\mathrm{C}-\mathrm{H}$ bonds between 3000 to 2870 $\mathrm{cm}^{-1}$ band, at $1730 \mathrm{~cm}^{-1}$ due to the presence of carbonyl groups $\mathrm{C}=\mathrm{O}$ and between $1060-1120$ $\mathrm{cm}^{-1}$ the $\mathrm{C}-\mathrm{O}$ link. 


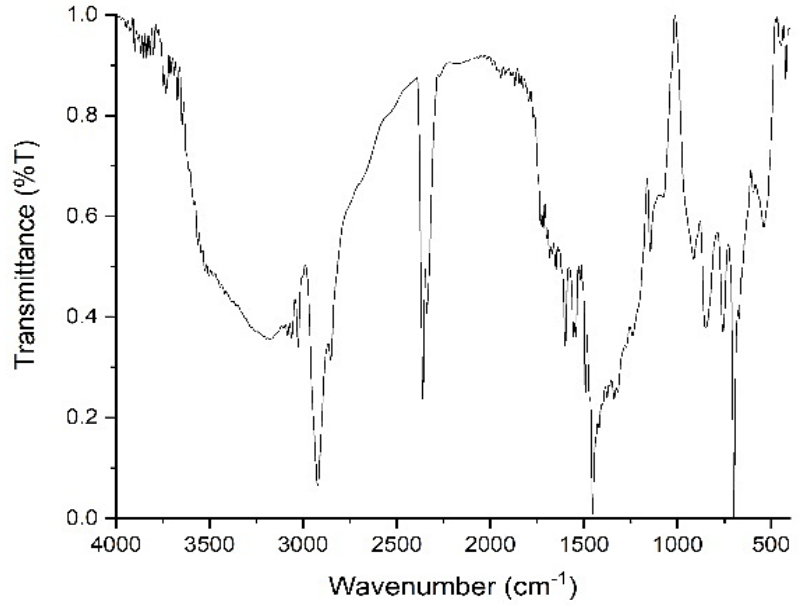

Graphic 3 PS/PMMA block coplymer IR spectrum

As can be seen in Graphics 4 and 5, the band in $2900 \mathrm{~cm}^{-1}$ shows a polymer peak where in the different percentages of magnetite. The higher percentage decreases and moves to 2800 $\mathrm{cm}^{-1}$, the other peak that decreases is between $1800-1600 \mathrm{~cm}^{-1}$ where the two peaks in the percentages 0.5 and 0.25 while in the $700 \mathrm{~cm}^{-1}$ where the magnetite is found. It is observed that the peak is growing as it decreases in the percentage amount of magnetite these, it should be that the incorporations causes the methacrylate molecules to tense due to this it can be said that the magnetic particles are within the polymeric matrices.

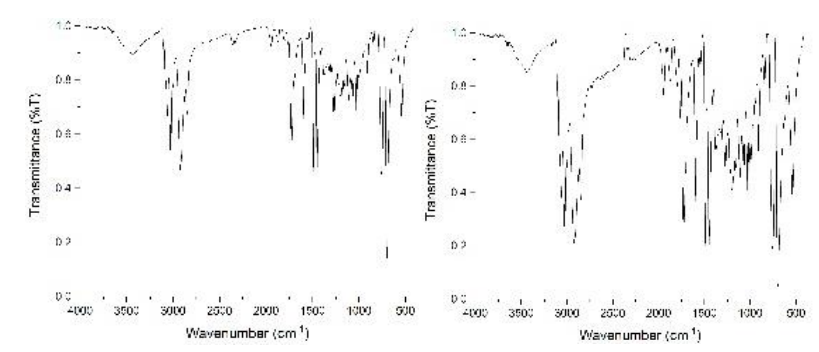

Graphic 4 PS/PMMA block copolymer coupling with magnetite $0.5 \%$ IR spectrum A) without sonication and B) sonicated

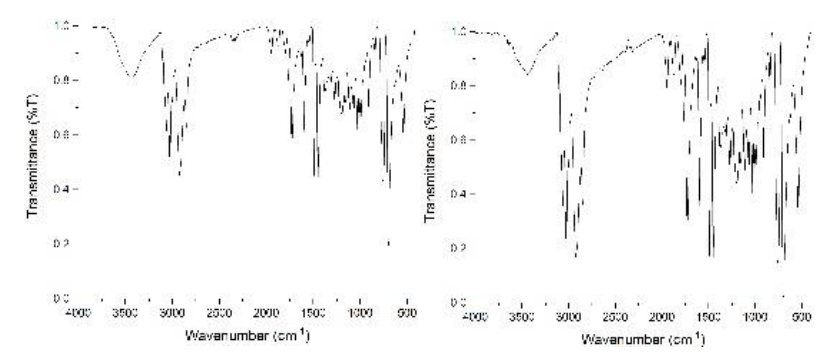

Graphic 5 PS/PMMA block copolymer coupling with magnetite $0.25 \%$ IR spectrum A) without sonication and B) sonicated
Likewise, the effect of the dispersion process via physical mixing by sonication and the in-situ process during the polymerization process can be seen in both graphics.

\section{Conclusions}

By means of the ultrasonic bath it is possible to obtain magnetic polymeric nanocomposites, with good stability for their applications. The stability and dispersion of polymeric nanocomposites depends on the molecular weight and viscosity of the polymer. At low viscosities, the nanoparticles disperse easily but are less stable than at high viscosities although dispersion requires more time.

The IR spectrum show us the incorporation of the ferromagnetic material with the block copolymer. The presence of the pick on the $700 \mathrm{~cm}^{-1}$ region it's characteristic of the magnetite, which is present in the Graphics 3, 4 and 5.

In the Graphics 4B and 5B we can prove than the process of sonication helps us increasing the coupling of the magnetite with the polymeric matrix, decreasing the percentage of transmittance in comparison of the Graphics 4A and $5 \mathrm{~A}$.

\section{Acknowledgement}

We are grateful to project 144 of the CIICUGTO-2020 call (Obtaining polymeric nanocomposites via heterophasic polymerization processes for the development of surface protection).

\section{References}

[1] H. Gonçalves, O., M. Asua, J., Henrique Hermes de Araújo, P., \& A. F. Machado, R. (2008). Synthesis of PS/PMMA Core-Shell Structured Particles by Seeded Suspension Polymerization. Macromolecules, 41(19), 6960-6964. https://doi.org/10.1021/ma800693m

[2] Vivaldo-lima, E., Wood, P. E., Hamielec, A. E., Penlidis, A., \& Equation, P. B. (1997). An Updated Review on Suspension Polymerization. 5885(905), 939-965. https://doi.org/10.1021/ie960361g 
[3] Yang, P., Wang, S., Teng, X., Wei, W., Dravid, V. P., \& Huang, L. (2012). Effect of magnetic nanoparticles on the morphology of polystyrene- b-poly(methyl methacrylate) diblock copolymer thin film. Journal of Physical Chemistry C, 116(43), 23036-23040.

https://doi.org/10.1021/jp305827x

[4] Xu, C., Ohno, K., Ladmiral, V., Milkie, D. E., Kikkawa, J. M., \& Composto, R. J. (2009). Simultaneous block copolymer and magnetic nanoparticle assembly in nanocomposite films. Macromolecules, 42(4),

1219-1228. https://doi.org/10.1021/ma8022266 